\title{
Penerapan Augmented Reality Berbasis Android Untuk Mengenalkan Pakaian Adat Tountemboan
}

\author{
Zwingly Ch Rawis, Virginia Tulenan, Brave A. Sugiarso \\ Teknik Informatika Universitas Sam Ratulangi . \\ Rawiszch@gmail.com, virginia.tulenan@unsrat.ac.id, brave@unsrat.ac.id
}

\begin{abstract}
Abstrak - Pakaian adat Tountemboan merupakan salah satu warisan kebudayaan yang ada di Minahasa. Pada zaman modern masalah yang dihadapi adalah kurangnya media untuk mengenalkan warisan-warisan kebudayaan yang ada, salah satunya Pakaian adat Tountemboan. Karena itu dibuatlah sebuah media informasi yang dapat mengenalkan Pakaian adat Tountemboan. Agar dapat di akses dengan mudah maka aplikasi dibuat berbasis android dan memanfaatkan teknologi Augmented Reality User Defined Target yang memungkinkan kita menambah objek virtual pada lingkungan nyata sehingga dapat mudah digunakan. Metode yang digunakan dalam penelitian ini adalah Multimedia Development Life Cycle. Penelitian ini menghasilkan sebuah aplikasi Augmented Reality Pakaian adat Tountemboan yang dapat membantu masyarakat umum, dan khususnya masyarakat Sulawesi Utara untuk mengenal Pakaian adat Tountemboan.
\end{abstract}

Kata kunci : Android, Augmented Reality, Multimedia Development Life Cycle, Pakaian adat Tountemboan, User Defined Target.

Abstract - Traditional clothing Tountemboan is one of the cultural heritage that exist in Minahasa. In modern times the problem is the lack of media to introduce the cultural heritages that exist, one of which Tountemboan custom clothing. Because it was made an information media that can introduce Tountemboan custom clothes. In order to be accessed easily then the application is based on android and utilize Augmented Reality Target User Defined technology that allows us to add virtual objects in real environment so that it can be easy to use. The method used in this research is Multimedia Development Life Cycle. This research produces an application of Augmented Reality Traditional Clothes Tountemboan that can help the general public, and especially the people of North Sulawesi to know Tountemboan custom clothes.

Keyword: Android, Augmented Reality, Multimedia Development Life Cycle,Tountemboan Traditional clothing, User Defined Target.

\section{PENDAHULUAN}

Pada setiap etnis masing-masing memiliki identitas. Identitas tersebut berupa bahasa, pakaian adat, ritual, rumah, makanan, dan minuman. Salah satu keberagaman dari budaya di Minahasa adalah Pakaian adat
Tountemboan. Karena kurangnya media informasi yang ada, kebudayaan Minahasa mulai terkikis dengan budayabudaya yang berasal dari luar daerah bahkan dari luar negeri.

Dalam melestarikan budaya di Sulawesi Utara lebih khusus untuk Pakaian adat Tountemboan, dapat digunakan suatu media informasi yang bisa membantu dalam memberikan informasi mengenai pakaian adat Tountemboan. Teknologi Augmented Reality merupakan media yang bisa mengenalkan informasi pakaian adat Tountemboan secara mudah dan real time kepada pengguna. Penggunaan Augmented Reality dapat membantu masyarakat Sulawesi Utara untuk mengenal pakaian adat Tountemboan dengan menggunakaan objek 2 dimensi dan berjalan pada sistem operasi android.

\section{A. Pakaian Adat}

Pakaian adalah sebuah barang yang dipakai, sedangkan adat adalah sebuah budaya atau cara (kelakuan dsb) yang sudah menjadi kebiasaan dan memiliki sebuah ciri khas (KBBI). Jadi pakaian adat merupakan simbol kebudayaa suatu daerah. Untuk menunjukan nama daerah pakaian adat pun bisa dijadikan simbol tersebut

\section{B. Pakaian adat Tountemboan}

Pada perkembangannya pakaian adat di Sulawesi Utara masih belum mempunyai bentuk yang pasti sampai pada tahun 1970-an. Pada saat Taman Mini Indonesia akan dibangun, pemerintah pusat mengharuskan setiap daerah menyertakan pakaian adat masing-masing daerah untuk mengisi Taman Mini Indonesia. Pada saat itulah pakaian adat Sulawesi Utara ini kemudian dirancang oleh Bernard Ginupit disepakati juga oleh Gubernur dan tua-tua adat Minahasa. Pakaian adat yang dibuat pertama kali adalah untuk Seluruh Sulawesi Utara termasuk Bitung, Bolaang Mongondow, dan Sangihe. Kemudian dalam perkembangannya untuk setiap suku, etnik, sub etnik dan daerah dibedakan dengan motif yang ada di suku, etnik, sub etnik daerah tersebut

Pakaian adat Tountemboan merupakan pakaian adat etnis Tountemboan dimana pakaian ini memiliki bentuk 
yang sama dengan pakaian adat Sulawesi Utara pada umumnya, namun pakaian adat Tountemboan memakai motif yang sesuai dengan lingkungan budaya dan adat sekitar yaitu aksara-aksara pada batu Pinawetengan yang erat etnis Tountemboan, bahkan Minahasa pada umumnya. Pakaian adat Tountemboan ini pada dasarnya memiliki fungsi yang sama dengan pakaian adat Sulawesi Utara.

\section{Augmented Reality.}

Augmented Reality merupakan teknologi yang menggabungkan benda maya (dua dimensi atau tiga dimensi) ke dalam sebuah lingkungan nyata lalu memproyeksikan benda-benda maya tersebut dalam waktu yang sama.Terdapat tiga karakteristik dari Augmented Reality menurut Azuma,yaitu :

1.) Mengkombinasikan kenyataan dan objek virtual dalam lingkungan nyata $3 \mathrm{D}$

2.) Berjalan secara interaktif dan waktu yang nyata

3.) Terdapat integrasi antar benda dalam tiga dimensi, yaitu benda maya terintegrasi dalam dunia nyata.

\section{Markerless Augmented Reality}

Markerless Augmented Reality merupakan tipe augmented reality yang tidak menggunakan marker untuk menambahkan objek virtual ke lingkungan nyata. Berdasarkan teknik pelacakan pola dari yang ditangkap perangkat penangkapan, Markerless AR dibagi menjadi dua teknik, yaitu:

1.) Pose Tracking

Teknik Pose Tracking bekerja dengan cara mengamati lingkungan yang static dengan perangkat keras augmented reality yang bergerak.

2.) Pattern Matching

Teknik Pattern Matching mirip dengan tipe Marker Based Augmented Reality, namun marker diganti dengan suatu gambar biasa.

\section{E. Vuforia}

Vuforia adalah salah satu Software Development Kit Augmented Reality (SDK) untuk perangkat mobile yang disediakan oleh Qualcomm untuk membantu para developer membuat aplikasi-aplikasi Augmented Reality (AR) di smartphone (iOS, Android). Vuforia memakai teknologi Computer Vision untuk mengenali dan melacak gambar (Image Target), dan objek 3D sederhana secara real time.

\section{F. User Defined Target}

Vuforia juga menyediakan fitur User Defined Target dimana gambar target ditetapkan pengguna saat runtime dari frame kamera yang dipilih oleh pengguna itu sendiri. Target yang ditentukan pengguna memungkinkan pengguna untuk memilih gambar saat runtime. Dengan demikian, pengguna merasakan AR "kapan saja, dimana saja".

\section{G. Unity $3 D$}

Unity adalah sebuah tools yang terintegrasi untuk membuat bentuk objek 3D pada Video Games, atau untuk konteks interaktif lain seperti Visualisas Arsitektur atau animasi 3D real-time. Lingkungan dari pengembangan Unity 3D berjalan pada Microsoft Windows dan Mac Os X, serta permainan yang dibuat oleh Unity dapat berjalan pada Windows, Mac, Xbox 360, Playstation 3, Wii, iPad, iPhone, dan tidak ketinggalan pada platform Android.

\section{H. Blender}

Blender adalah perangkat lunak open source grafika komputer 3D. Perangkat lunak ini digunakan untuk membuat film animasi, efek visual, model cetak 3D, aplikasi 3D interaktif dan video game. Blender memiliki beberapa fitur termasuk pemodelan 3D, penteksturan, penyunting gambar bitmap, penulangan, simulasi cairan dan asap, simulasi partikel, animasi bahkan video editing dan pembuatan game.

\section{Android}

Android adalah sistem operasi yang digunakan di smartphone dan juga tablet PC. Fungsinya sama seperti sistem operasi Symbian di Nokia, iOS di Apple dan BlackBerry OS.. Android dibuat dengan basis kernel Linux yang telah dimodifikasi, dan untuk setiap release-nya diberi kode nama berdasarkan nama hidangan makanan.

\section{J. Multimedia}

Multimedia juga bisa berarti kombinasi dari paling sedikit dua media input atau output. Multimedia pun bisa dibagi menjadi dua kategori, yaitu multimedia linier dan multimedia interaktif. Multimedia linier adalah multimedia yang tidak dilengkapi dengan alat pengontrol yang dapat dioperasikan oleh pengguna. Multimedia pembelajaran dapat diartikan sebagai aplikasi multimedia yang digunakan dalam proses pembelajaran, dan itu juga untuk menyalurkan pesan (pengetahuan, sikap dan keterampilan) serta dapat merangsang pikiran, perasaan, perhatian dan kemauan yang belajar sehingga secara sengaja proses belajar terjadi, bertujuan, terarah, dan terkendali.

Elemen-elemen Multimedia :

1.) Teks

Teks merupakan elemen multimedia yang menjadi dasar untuk menyampaikan informasi, karena teks adalah jenis data yang paling sederhana dan membutuhkan tempat penyimpanan yang paling kecil. Teks merupakan cara yang paling efektif dalam mengemukakan ide-ide kepada pengguna, sehingga penyampaian informasi akan lebih mudah dimengerti oleh masyarakat. 


\section{2.) Grafik (image)}

Sangat bermanfaat untuk mengilustrasi informasi yang akan disampaikan terutama informasi yang tidak dapat dijelaskan dengan kata-kata. Jenis-jenis grafik seperti bitmap yaitu gambar yang disimpan dalam bentuk kumpulan pixel, yang berkaitan dengan titik-titik pada layar monitor.

3.) Audio

Multimedia tidak akan lengkap jika tanpa audio (suara). Audio bisa berupa percakapan, musik atau efek suara. Format dasar audio terdiri dari beberapa jenis :

a. Wave

Merupakan format file digital audio yang disimpan dalam bentuk digital dengan eksistensi WAV

b. MIDI (Musical Instrument Digital Interface) MIDI memberikan cara yang lebih efisien dalam merekam music dibandingkan wave, kapasitas data yang dihasilkan juga jauh lebih kecil. MIDI disimpan dalam bentuk MID.

4.) Video

Video menyediakan sumber yang kaya dan hidup untuk aplikasi multimedia. Dengan video dapat menerangkan hal-hal yang sulit digambarkan lewat kata-kata atau gambar diam dan dapat menggambarkan.

\section{5.) Animasi}

Animasi adalah simulasi gerakan yang dihasilkan dengan menayangkan rentetan frame ke layer. Frame adalah satu gambar tunggal pada rentetan gambar yang membentuk animasi.

\section{K. Unified Modeling Languange}

UML adalah bahasa untuk menspesifikasi, memvisualisasi, membangun dan mendokumentasikan artifacts (bagian dari informasi yang digunakan untuk dihasilkan oleh proses pembuatan perangkat lunak, artifact tersebut dapat berupa model, deskripsi atau perangkat lunak)dari sistem perangkat lunak, seperti pada pemodelan bisnis dan sistem non perangkat lunak lainnya.

\section{1.) Use Case}

Use Case adalah metodologi yang digunakan dalam analisis sistem untuk mengidentifikasi, mengklarifikasi, dan mengatur persyaratan sistem. Use Case terdiri dari sekumpulan kemungkinan-kemungkinan interaksi antara sistem dan pengguna di lingkungan tertentu dan terkait dengan tujuan tertentu.Use Case Node dapat dilihat pada gambar 1 .

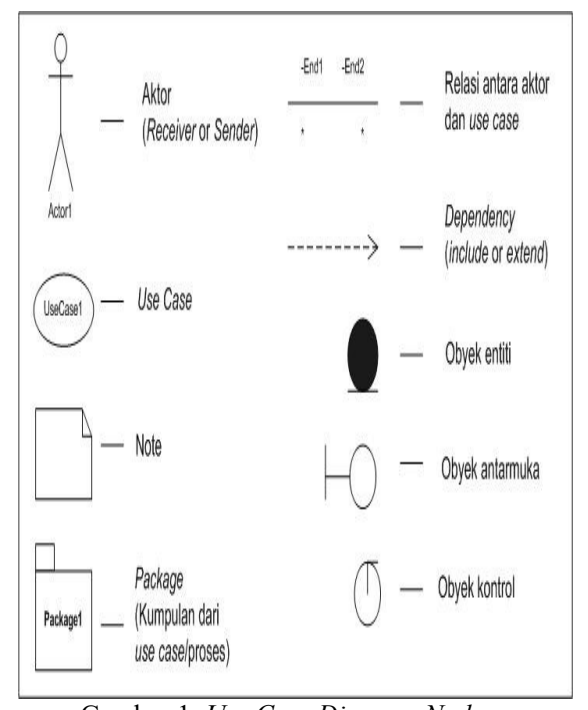

Gambar 1. Use Case Diagram Node

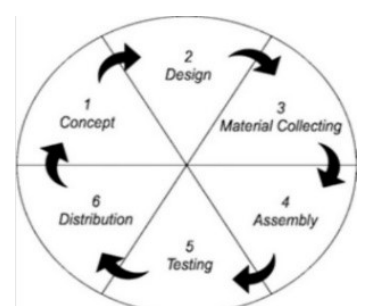

Gambar 2. Multimedia Development Life Cycle

\section{2.) Activity Diagram}

Menggambarkan rangkaian aliran dari aktivitas, digunakan untuk mendeskripsikan aktifitas yang dibentuk dalam suatu operasi sehingga dapat juga digunakan untuk aktifitas lainnya seperti use case atau interaksi.Penjelasan Node dapat dilihat pada tabel 1 .

\section{Multimedia Development Life Cycle}

Multimedia Development Life Cycle Menurut Binanto (2010) yang dikutip dari Luther (1994), merupakan metode pengembangan multimedia terdiri dari enam tahap, yaitu Concept, Design, Material Collecting, Assembly, Testing, dan Distribution. Keenam tahap ini tidak harus berurutan dalam praktiknya, tahap-tahap tersebut dapat saling bertukar posisi. Meskipun begitu, tahap Concept memang harus menjadi hal yang pertama dikerjakan. Pada gambar 2 menunjukan alur dari Multimedia Development Life Cycle

1.) Concept.

Tahap concept adalah tahap untuk menentukan tujuan dan siapa pengguna program

2.) Design

Design adalah tahap pembuatan spesifikasi mengenai arsitektur program, gaya, tampilan, dan kebutuhan material/bahan untuk program.

3.) Material Collecting 
Tahap ini adalah pengumpulan bahan sesuai dengan kebutuhan yang dikerjakan. Bahan-bahan tersebut, antara lain gambar clip art, foto, animasi, video, audio, dan lain-lain yang diperoleh secara gratis atau dengan pemesanan kepada pihak lain sesuai dengan rancangannya.

4.) Assembly.

Tahap assembly adalah tahap pembuatan semua objek atau bahan multimedia.

5.) Testing

Tahap Testing dilakukan setelah menyelesaikan tahap pembuatan (assembly) dengan menjalankan aplikasi/program dan melihatnya apakah ada kesalahan atau tidak.

6.) Distribution

Pada tahap ini, aplikasi akan disimpan dalam suatu media penyimpanan. Tahap ini juga disebut tahap evaluasi untuk pengembangan produk yang sudah jadi supaya lebih baik.

\begin{tabular}{|c|c|c|}
\hline Gambar & Nama & Keterangan \\
\hline & Activity & $\begin{array}{l}\text { Memperlihatkan } \\
\text { masing-masing kelas } \\
\text { antarmuka saling } \\
\text { berinteraksi satu sama } \\
\text { lain }\end{array}$ \\
\hline & Action & $\begin{array}{l}\text { State dari sistem yang } \\
\text { mencerminkan } \\
\text { eksekusi dari suatu } \\
\text { aksi }\end{array}$ \\
\hline & Initial Node & $\begin{array}{l}\text { Bagaimana objek } \\
\text { dibentuk atau diawali }\end{array}$ \\
\hline & Activity Final Node & $\begin{array}{l}\text { Bagaimana } \\
\text { dibentuk } \\
\text { dihancurkan }\end{array}$ \\
\hline & Fork Node & $\begin{array}{l}\text { Satu aliran yang pada } \\
\text { tahap tertentu berubah } \\
\text { menjadi beberapa } \\
\text { aliran }\end{array}$ \\
\hline
\end{tabular}

\section{Black Box Testing}

Pengujian kotak hitam, juga disebut pengujian perilaku, berfokus pada persyaratan fungsional perangkat lunak. Artinya, pengujian kotak hitam memungkinkan insinyur perangkat lunak untuk memperoleh serangkaian kondisi masukan yang akan sepenuhnya melaksanakan semua persyaratan fungsional untuk sebuah program. Dengan menggunakan teknik pengujian kotak hitam, penguji memeriksa rancangan tingkat tinggi dan spesifikasi persyaratan pelanggan untuk merencanakan uji kasus untuk memastikan kode tersebut melakukan apa yang dimaksudkannya. Pengujian fungsional melibatkan memastikan bahwa fungsi yang ditentukan dalam Spesifikasi kebutuhan bekerja. Sistem pengujian melibatkan menempatkan program baru di lingkungan yang berbeda untuk memastikan program bekerja di lingkungan pelanggan yang khas dengan berbagai versi dan jenis sistem operasi dan / atau aplikasi. Pengujian sistem adalah pengujian yang dilakukan pada sistem yang lengkap dan terpadu untuk mengevaluasi kepatuhan sistem terhadap persyaratan yang ditentukan (Laurie Williams, 2006, p39).

\section{METODE PENELITIAN}

\section{A. Kerangka Penelitian}

Dalam melakukan penelitian dilakukan kerangka yang akan menuntun peneliti. Pada gambar 3 menujukan kerangka piker yang digunakan peneliti.

\section{B. Tahapan Pembuatan Perangkat Lunak}

Metode Multimedia Development Life Cycle ini memungkinkan pada saat pembuatan pengambilan data dan pengumpulan materi bisa dilakukan kembali jika data dan materi masih kurang, juga metode ini memungkinkan tahap pengumpulan data dan pembuatan dapat berjalan secara bersamaan.

\section{1.) Konsep}

Pada tahap ini dilakukan pengumpulan data awal berupa kuesioner untuk mendapatkan spesifikasi aplikasi yang akan dibuat yang dapat dilihat pada tabel 2.

\section{2.) Desain}

Pada tahap ini dilakukan pembuatan storyboard, use case, dan activity diagram yang akan digunakan sebagai acuan elemen-elemen pada aplikasi.

a. Use Case Diagram.

Pada gambar 4 menampilkan interaksiinteraksi antara use case, actor dan sistem

b. Activity Diagram.

Pada gambar 5, 6, 7, dan 8 menampilkan aktifitas-aktifitas yang akan terjadi pada aplikasi.

3.) Pengumpulan Materi.

Pada tahap ini peneliti akan mengumpulkan materi berupa pakaian yang akan dimasukan pada aplikasi Augmented Reality yang diambil dari buku serta jurnal terkait juga dilakukan wawancara dengan para budayawan(lihat table 1 dan 2). Pengumpulan materi juga dilakukan dengan mewawancarai pegawai Balai Pelestarian Nilai Budaya untuk mendapatkan detail pakaian adat tountemboan(lihat gambar 9).

4.) Perakitan

Pada gambar 9, 10, dan 11 merupakan perakitan yang dibuat sesuai dengan desain yang telah dibuat sebelumnya dan memasukan kode sumber untuk fungsi-fungsi pada aplikasi 


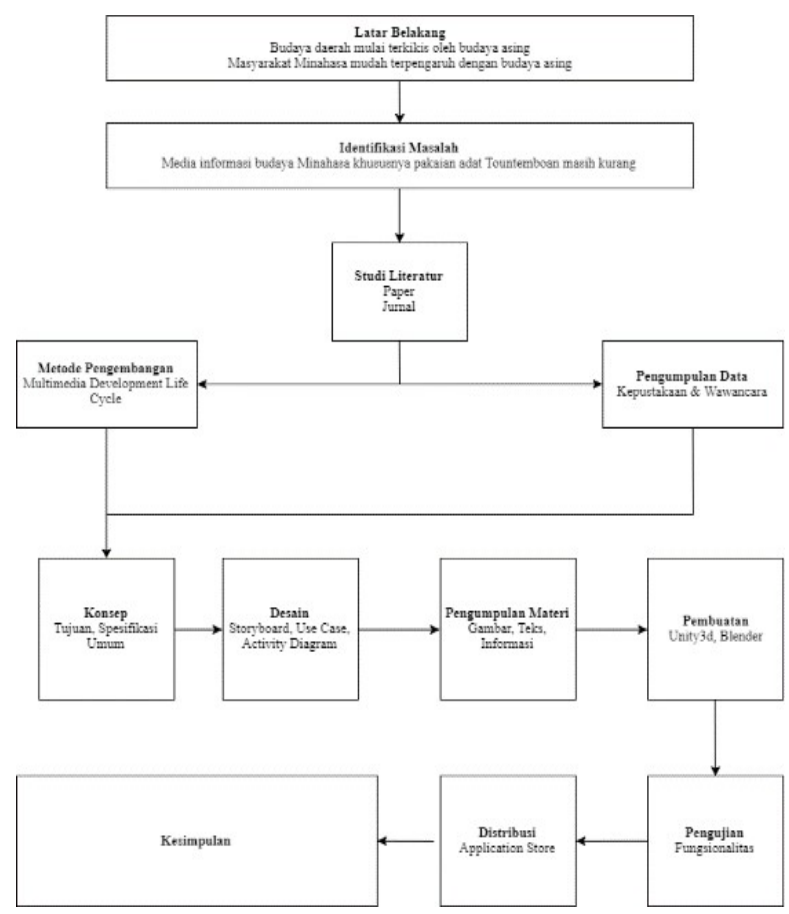

Gambar 3. Kerangka Berpikir.

TABEL II. SPESIFIKASI APLIKASI

\begin{tabular}{|c|c|}
\hline Judul & Penerapan Augmented Reality Untuk \\
\hline & Mengenalkan Pakaian Adat Tountemboan \\
\hline Tujuan & $\begin{array}{l}\text { Mengenalkan warisa budaya Minahasa yaitu } \\
\text { pakaian Tountemboan dengan tepat melalui } \\
\text { Teknologi Augmented Reality }\end{array}$ \\
\hline Gambar & Menggunakan format file.png untuk aplikasi \\
\hline Audio & Wav \\
\hline Pengguna Akhir & Masyarakat umum \\
\hline Objek Virtual & Gambar 2 dimensi pakaian adat Tountemboan \\
\hline Input & Objek bebas 2 dimensi \\
\hline Output & Objek 2 dimensi pakaian adat Tountemboan \\
\hline
\end{tabular}

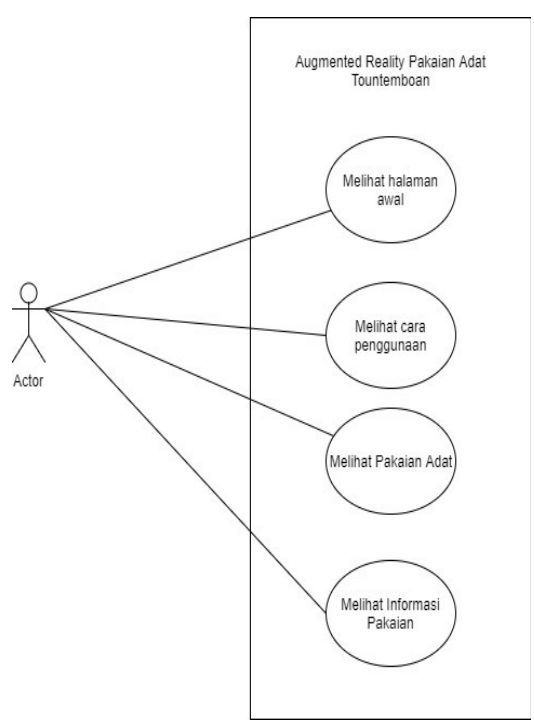

Gambar 4. Use case Diagram

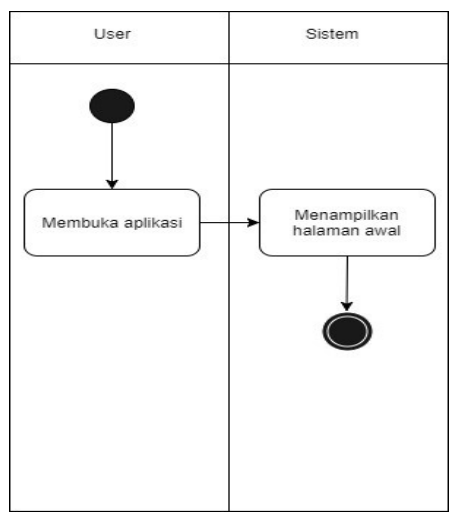

Gambar 5. Activity Diagram Buka Aplikasi

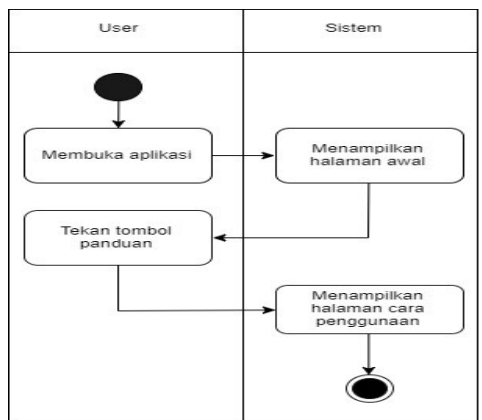

Gambar 6. Activity Diagram Cara Penggunaan

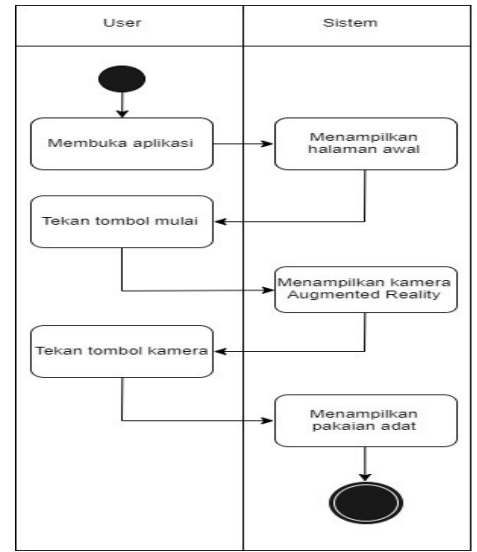

Gambar 7.Activity Diagram Tampilkan Pakaian Adat

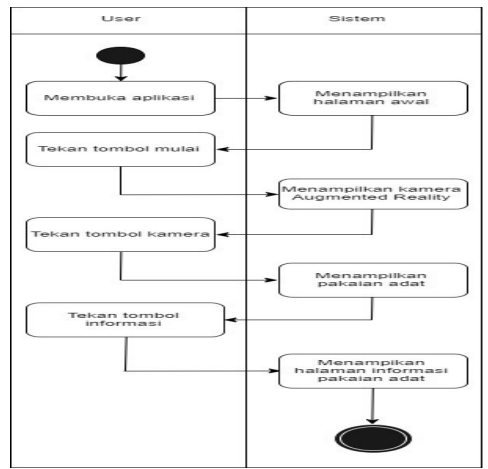

Gambar 8. Activity Diagram informasi Pakaian Adat 

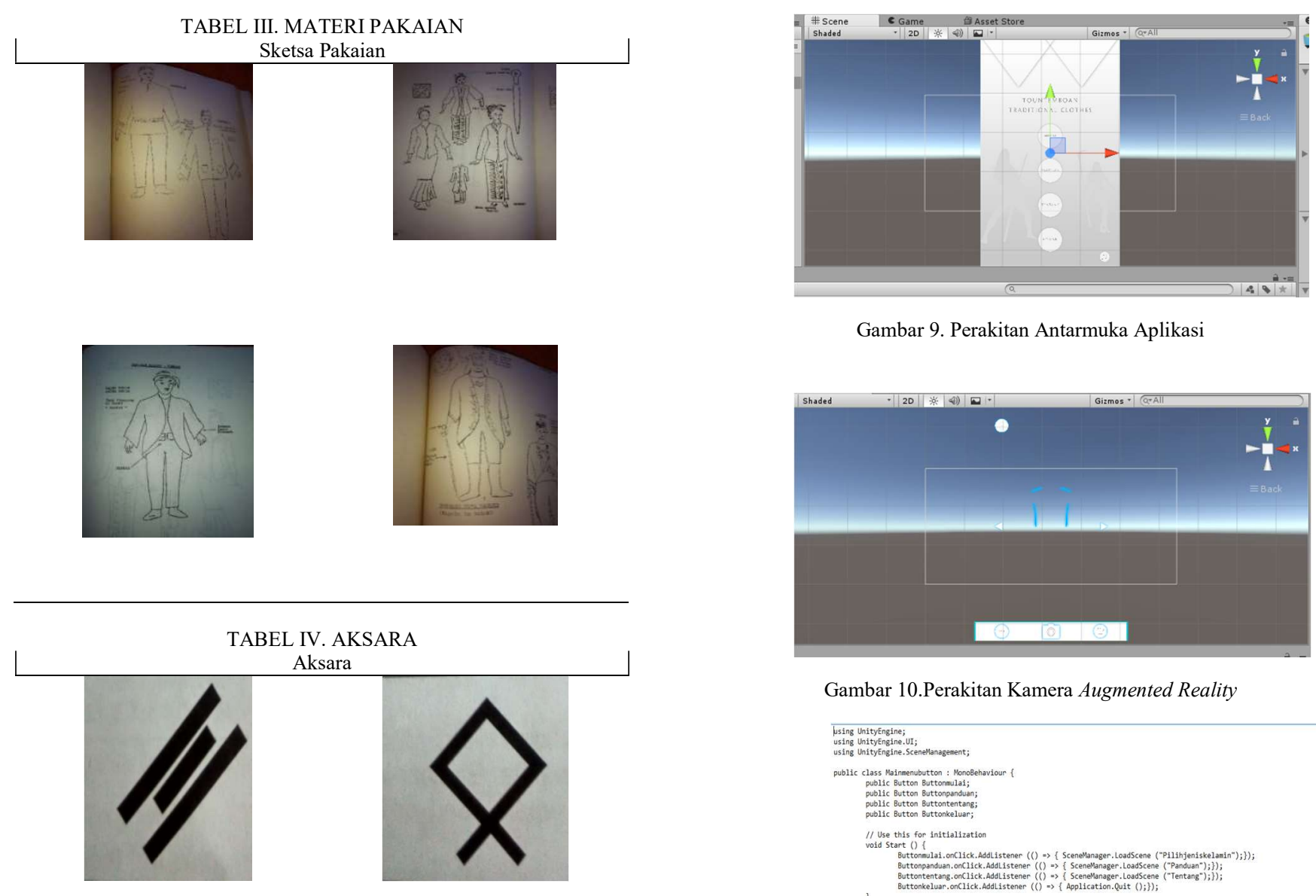

Gambar 9. Perakitan Antarmuka Aplikasi

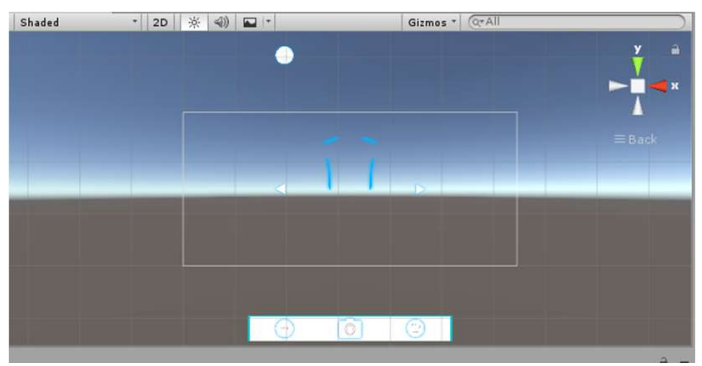

Gambar 10.Perakitan Kamera Augmented Reality
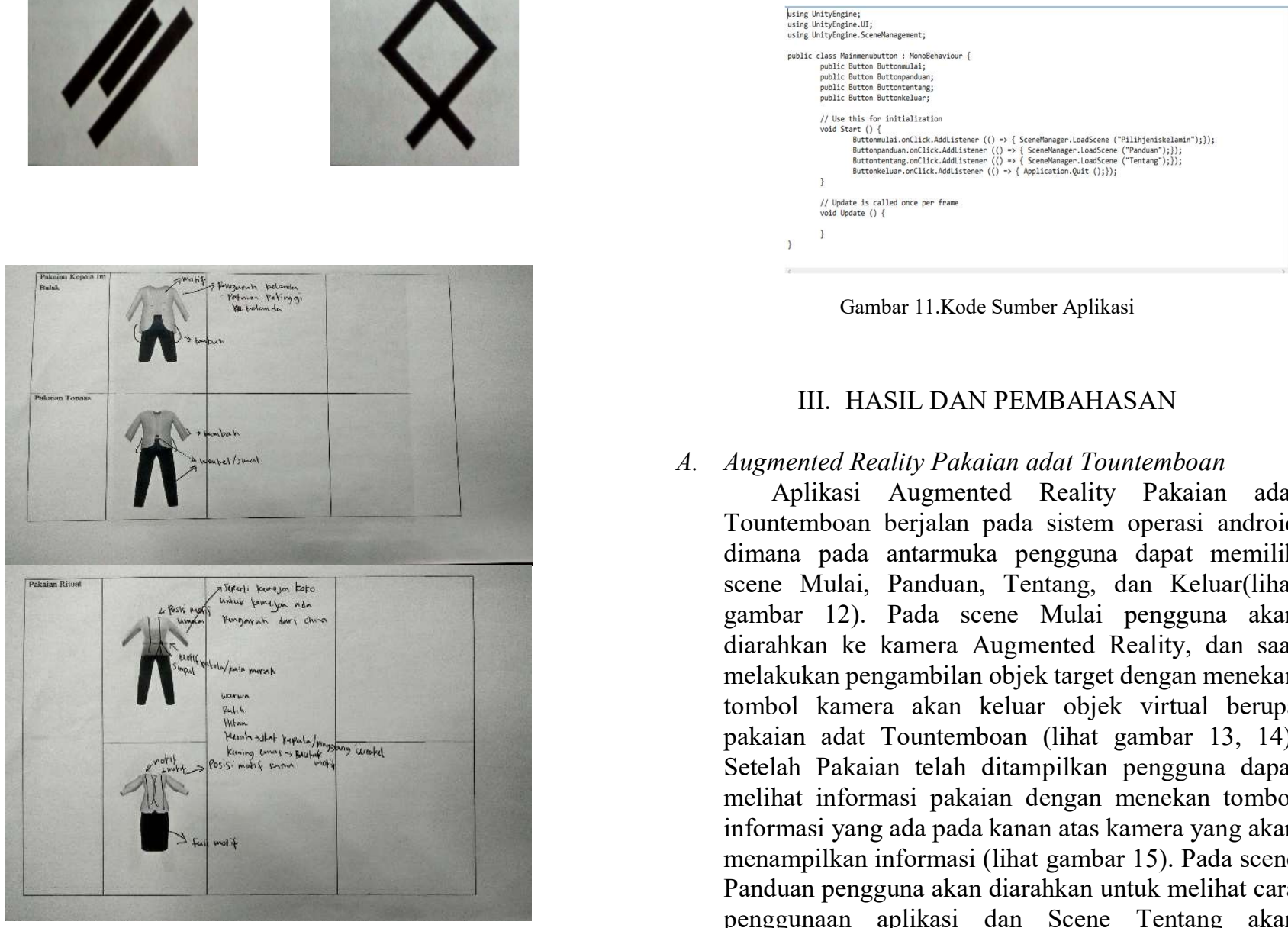

Gambar 11.Kode Sumber Aplikasi

\section{HASIL DAN PEMBAHASAN}

\section{A. Augmented Reality Pakaian adat Tountemboan}

Aplikasi Augmented Reality Pakaian adat Tountemboan berjalan pada sistem operasi android dimana pada antarmuka pengguna dapat memilih scene Mulai, Panduan, Tentang, dan Keluar(lihat gambar 12). Pada scene Mulai pengguna akan diarahkan ke kamera Augmented Reality, dan saat melakukan pengambilan objek target dengan menekan tombol kamera akan keluar objek virtual berupa pakaian adat Tountemboan (lihat gambar 13, 14). Setelah Pakaian telah ditampilkan pengguna dapat melihat informasi pakaian dengan menekan tombol informasi yang ada pada kanan atas kamera yang akan menampilkan informasi (lihat gambar 15). Pada scene Panduan pengguna akan diarahkan untuk melihat cara penggunaan aplikasi dan Scene Tentang akan mengarahkan pengguna untuk melihat informasi dari Pengembang (lihat gambar 16). 

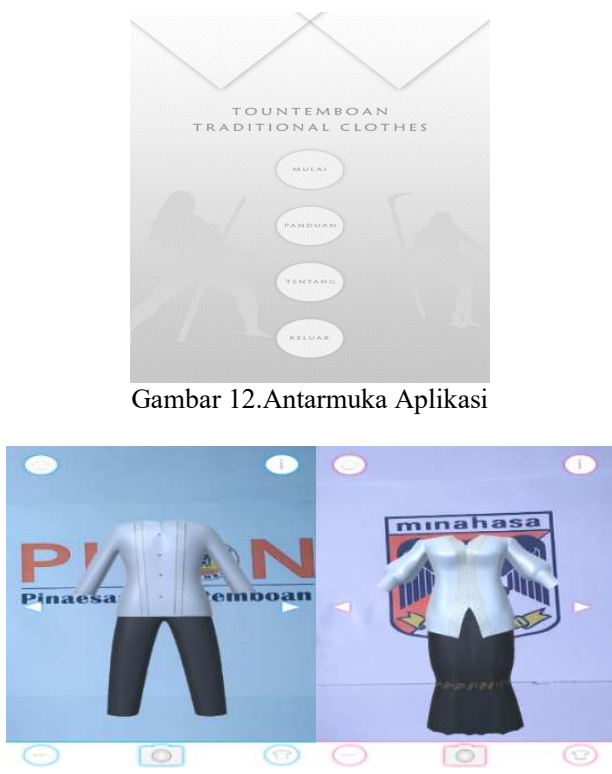

Gambar 13.Pakaian Ritual Pria dan Wanita

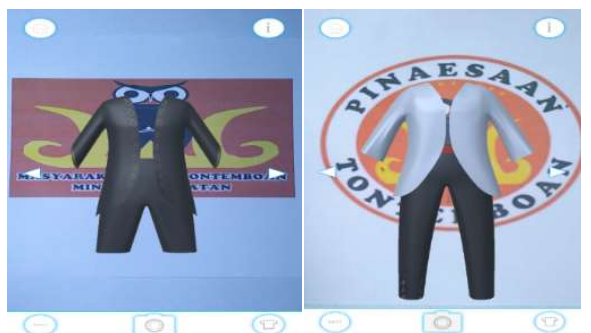

Gambar 14.Pakaian Kepala Im Balak dan Pakaian Tonaas

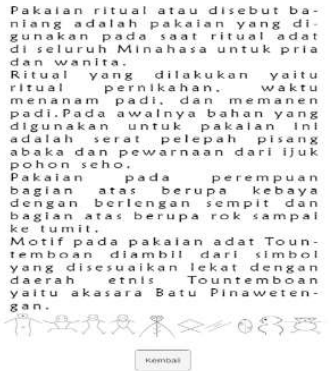

Gambar 15.Informasi Pakaian Adat

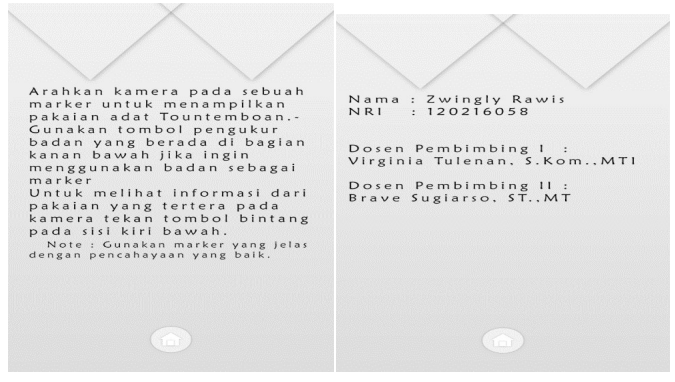

Gambar 16.Cara Penggunaan Aplikasi dan tentang

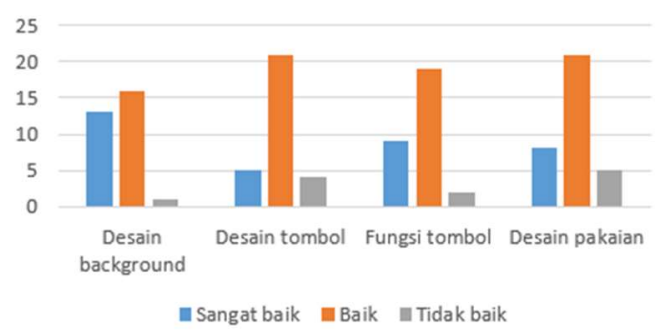

Gambar 17. Pengujian Pengguna

\section{5.) Pengujian}

Setelah aplikasi selesai dibuat,dilakukan pengujian yang dilakukan oleh pengguna untuk melihat respon dari penguna mengenai fungsi dan desain aplikasi. Peneliti memakai jumlah responden sebanyak 30 orang untuk melakukan percobaan dan didapatlah hasil seperti pada gambar 20.

\section{PENUTUP}

\section{A. Kesimpulan}

Berdasarkan penelitian yang dilakukan dalam Penerapan Augmented Reality untuk mengenalkan Pakaian adat Tountemboan diambil kesimpulan:

1. Dihasilkan aplikasi Augmented Reality pakaian adat Tountemboan untuk mengenalkan pakaian adat Tountemboan dengan menggunakan Metode Multimedia Development Life Cycle.

2. Aplikasi Augmented Reality Pakaian adat Tountemboan dapat mengenalkan informasi mengenai Pakaian adat Tountemboan.

B. Saran

Saran yang ingin disampaikan untuk pengembangan lebih lanjut untuk penelitian ini adalah sebagai berikut:

1. Penerapan Augmented Reality dengan objek 3 dimensi dan implementasi motif serta hiasan untuk menghasilkan informasi pakaian yang lebih detail pada bentuk juga lebih fleksible untuk teknik markerless.

2. Penggunaan Teknologi Augmented Reality untuk memperluas media informasi yang ada dalam mengenalkan warisan budaya daerah Sulawesi Utara.

\section{DAFTAR PUSTAKA}

[1]. A. Y. A. F. W. H. Agung Tri Yunanto, "Penciptaan Buku Ilustrasi Pakaian Adat Bregada Hadiningrat Kraton Yogyakarta Sebagai Upaya Pengenalan Pakaian Tradisional Kepada Anak-anak," Art Nouveau, p. 3, 2015. 
[2]. S. R. S. S. D. K. Auliawati Buchari, "Implementasi Augmented Reality Warisan Budaya Berwujud di Museum Propinsi Sulawesi Utara," E-Jurnal Teknik Informatika, p. 1, 2015.

[3]. V. T. B. S. Christy Laura Kilmanun, "Pengenalan Rumah Sakit Umum Propinsi Prof.Dr.R.D. Kandou di Kota Manado Berbasis Augmented Reality," E-Jurnal Teknik Elektro dan Komputer, p. 2, 2016.

[4]. W. T. P. P. Koapaha Gerald, "Perancangan Aplikasi Navigasi Denah 3D Pada Rumah Sakit Umum Daerah Bitung Menggunakan Game Engine Berbasis Android," in Konfrensi Nasional Sistem Informasi, Manado, 2015.

[5]. K. A. S. Andiny Oktariana, "Aplikasi Augemented Reality Pengenalan Lingkungan Perpustakaan Universitas Gunadarma Berbasis Desktop," in Konfrensi Nasional Sistem Informasi, Makassar, 2014.

[6]. R. S. A. W. Kerin Luciana Kereh, "Pengenalan TokohTokoh Pahlawan Nasional Indonesia Menggunakan Augmented Reality Berbasis Android," in Konfrensi Nasional Sistem Informasi, Manado, 2015.

[7]. H. W. J. R. S. K. Hendro Saputra Suratinoyo, "Cerita Rakyat Daerah Minahasa : Implementasi Short Film Animasi 3D," E-Jurnal Teknik Informatika, p. 1.

[8]. A. S. L. B. S. I Wayan S.A. Mukti, "Rancang Bangun Aplikasi Pembelajaran Untuk Anak Umur 6-9 Berbasis Android," E-Jurnal Teknik Informatika, p. 2, 2016.

[9]. M. M. Latif, "Aplikasi Augmented Reality Sebagai Media Pengenalan Batik Nusantara Berbasis Android," 2014.

[10]. A. A. S. X. B. N. Ishak U.Saputra, "Pengembangan Aplikasi Location Based Service Pariwisata Berbasis Android Studi Kasus Kabupaten Toraja Utara," E-Jurnal Teknik Informatika, 2017.

[11]. S. S. S. K. Sheila Claudy Riady, "Rancang Bangun Aplikasi Mobile Learning Anak Sekolah Minggu Dengan Teknologi Augmented Reality Berbasis Android," Teknik Informatika, 2016.

[12]. R. T. Azuma, "A Survey of Augmented Reality," Hughes Research Laboratories, Malibu Canyon Road, 1997.

[13]. A. S. M. L. D. J. M. Christman Toding, "Pembuatan Animasi 3 Dimensi Perbedaan Sampah Organik dan Anorganik untuk Anak-Anak," E-Jurnal Teknik Informatika, 2017.

[14]. A. S. M. L. B. A. S. I wayan S. A. Mukti, "Rancang Bangun Aplikasi Pembelajaran Untuk Anak Umur 6 - 9 Tahun Berbasis Android," E-Jurnal Teknik Informatika, 2016.

[15]. "MULTIMEDIA," in Konsep \& Aplikasi dalam Pendidikan, Bandung, Alfabeta, 2012, p. 2.
[16]. A. C. E. C. B. M. Brogni A., "Technological Approach for Cultural Heritage: Augmented Reality".

[17]. N. D. A. H. \&. N. Y. Nor Farhah Saidin, "A Review of Research on Augmented Reality in Education: Advantages and Applications," International Education Studies, 2015.

[18]. R. S. S. K. Meylisa Rasjid, "Rancang Bangun Aplikasi Alat Musik Kolintang menggunakan Augmented Reality berbasis Android," E-Jurnal Teknik Informatika, 2016.

[19]. D. P. D. KEBUDAYAAN, Arti Lambang dan Fungsi Tata rias Pengantin Dalam Menanamkan Nilai-Nilai Budaya Sulawesi Utara, Manado, 1984/1985.

[20]. R. M. Kolibu, "Kain Pinawetengan:Eksistensi Falsafah Lokal Dalam Kemasan Global," Jurnal Hasil Penelitian Sejarah dan Budaya Esagenang, p. 77, 2015.

\section{SEKILAS TENTANG PENULIS}

Sekilas dari penulis dengan nama Zwingly Rawis anak kedua dari dua bersaudara. Lahir di Warisa 19 oktober 1994. Dengan latar belakang pendidikan Sekolah Dasar GMIM Warisa, Sekolah Menengah Pertama Negeri 8 Manando ,Sekolah Menengah Atas lulus pada tahun 2012. Penulis kemudian melanjutkan studi di Fakultas Teknik, Jurusan

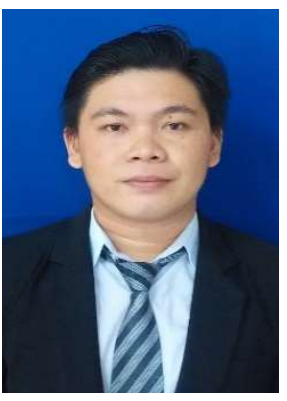
Elektro, Program Studi Informatika, Universitas Sam Ratulangi Manado. Pada tahun 2018 penulis membuat skripsi demi memenuhi syarat Sarjana (S1) dengan penelitian berjudul "Penerapan Augmented Reality Berbasis Android Untuk Mengenalkan Pakaian Adat Tountemboan". 